\title{
Mobile Shopping Consumers' Behavior: An Exploratory Study and Review
}

\section{Vaggelis Saprikis ${ }^{1}$, Angelos Markos ${ }^{2}$, Theodora Zarmpou ${ }^{3}$ and Maro Vlachopoulou ${ }^{4}$}

\author{
${ }^{1}$ Western Macedonia University of Applied Sciences, Department of Business Administration, Kozani \& Grevena, \\ Greece, saprikis@gmail.com \\ 2 Democritus University of Thrace, Department of Primary Education, Alexandroupolis, Greece, \\ amarkos@eled.duth.gr \\ ${ }^{3}$ University of Macedonia, Department of Applied Informatics, Thessaloniki, Greece, tzarmpou@gmail.com \\ ${ }^{4}$ University of Macedonia, Department of Applied Informatics, Thessaloniki, Greece, mavla@uom.gr
}

Received 20 February 2017; received in revised form 20 June 2017; accepted 16 August 2017

\begin{abstract}
Mobile Technology is creating a range of tremendous opportunities and new revenue streams for businesses across industry sectors through the delivery of chargeable mobile products and services via the deployment of innovative value-added solutions that exploit the commercial benefits of mobility. To keep up with the pace of change, companies increasingly want to understand the behavioral attitude of the modern mobile consumer. The aim of this paper is to find out users' reaction towards different parameters that would influence their intention to utilize their mobile devices in order to purchase products and services online focusing on the current Greek reality. The extant literature focuses on understanding the factors that might affect consumers' behavior intention to adopt $\mathrm{m}$-shopping; these studies are mostly based on behavioral intention theories, such as Technology Acceptance Model, Diffusion of Innovation and Unified Theory of Acceptance and Use of Technology. In this study, new theoretical constructs are combined with existing evidence in order to extend the Technology Acceptance Model as it was initially established by Davis and later further enriched by other researchers. The proposed model includes behavioral intention, mobile skillfulness, enjoyment, anxiety, perceived usefulness, perceived ease of use, trust, relationship drivers, and innovativeness.
\end{abstract}

Keywords: Mobile consumers' behavior, Mobile shopping drivers, Mobile shopping intention, Innovativeness, Trust, Relationship drivers, Enjoyment, Mobile skillfulness, SEM (Structural Equation Modeling) 


\title{
1 Introduction
}

In recent years, with the advancement of Information and Communication Technologies (ICT), the popularization of mobile devices, and the guidance and coordination of regulatory bodies, mobile commerce (m-commerce) has been one of the hottest trends in the internet. However, although the m-shopping idea is not new and has been in reality for more than 10 years [32], [38], [53], the actual revolution came with the launch of advanced mobile devices in the market, with smartphones and tablets leading the way; and the immense popularity of mobile applications followed [38], [65], [75], [89]. Mobile technology, nowadays, has penetrated almost in every aspect of our daily life and $\mathrm{m}-$ commerce has become an alternative approach for searching, comparing and buying products and services online anywhere and anytime [38], [45], [64], [111]. This trend makes researching the adoption and further use of $\mathrm{m}$ commerce very important to the academia and the industry as well. Mobile Consumers refer to individuals that may need or want to wirelessly interact with service providers to procure some specific service for personal purposes.

\subsection{Mobile Commerce - Shopping Evolution}

According to [62], the volume of m-commerce is growing at 39 percent each year and was estimated to have reached US $\$ 31$ billion by 2016 . The increased mobile phone usage during daily activities, and new areas of mobile integration such as m-Payments, reveals that the connected-consumer is here to stay [28].

\begin{abstract}
Mobile devices have reached critical mass, with a majority of consumers, $80 \%$ of global consumers in both developed and high-growth economies, now owning a mobile phone. Still a relatively new application, m-Payment usage is gaining traction globally. $47 \%$ of the consumers in emerging markets reported using their phones to make in-store payments. In developed markets, $20 \%$ of the consumers reported using their phones to make in-store payments and 30\% indicated interest. In developed markets, more northern Europeans use m-Payments for transport whereas central and southern Europe uses them more on food / shopping (lifestyle). One-third of ecommerce's business worldwide is transacted via mobile devices, and the number of smartphone and/or tablet users making purchases on their mobile devices will increase significantly in the years ahead [99].
\end{abstract}

With the consumer shift to mobile-first now fully underway, brands and marketers are constantly seeking to better understand consumer mobile preferences, transforming their mobile operating models, strategies and processes, while answering consumer demand for more personalized and contextually-relevant experiences, as well as instant access to products and services. When in stores, mobile shoppers tend to scan product barcodes and read reviews more often than computer-based shoppers and therefore "require different sales, marketing and service strategies" [32]. Mobile shoppers want the benefits of personalization without the downsides. Mobile consumers are $46 \%$ more willing than computer-based buyers to provide information, if the result is a more personalized experience. Therefore, they are willing to share their personal data and shopping preferences only within loyalty and rewarding programs [14].

So, it can be surely inferred that the m-shopping channel has emerged as an influential medium for connecting customers with retailers and ultimately in generating sales [112]. Given the continuing growth and the dynamics of $\mathrm{m}$-commerce, its comprehensive understanding has become a pursuit of various researchers and practitioners. Thus, several studies have been carried out in the $\mathrm{m}$-shopping field from different perspectives, including $\mathrm{m}$-commerce theory, wireless network infrastructure, mobile middleware, wireless user infrastructure, and $\mathrm{m}$-commerce applications and cases [74], [116]; trying to gain an improved insight into users' mobile behavior. However, the vast majority of them have focused on mobile services in general, whereas the examination of mobile shopping in the field of conducting a monetary transaction has been slightly studied [116]. Identifying key influential factors that impact mobile users on m-commerce can definitely help involved enterprises to formulate a target-oriented business strategy in order to improve customers' satisfaction. Therefore, the purpose of this paper is to find out users' reaction towards different parameters that would influence their intention to utilize their mobile devices in order to purchase products and services online; focusing on the current Greek reality. More specifically, the study aims to construct an instrument in order to provide an explanation of the determinants of $\mathrm{m}$-commerce acceptance. The study suggests a conceptual model that shows how its different constructs influence users to adopt m-commerce. Based on Greece's geographical and cultural characteristics, it is expected that the hypotheses used can explain the intention phenomenon. Such a study in the mobile domain has not yet been investigated for this culture. The paper is expected to both contribute research and practice by providing enlightenment and thoughts for the academia and industry to build strategies on m-shopping development.

\subsection{Behavioral Intention Theoretical Background}

A literature review on information systems, innovative technology, e-commerce and m-shopping highlights a number of theories or conceptual models, which are commonly used or extended with other variables for investigating various contexts of technology adoption and especially the users' intention to adopt m-services, as well as consumers' reaction towards factors affecting their intention to use their mobile devices in order to purchase 
products and services. Therefore, there are several behavioral intention theories, and the most popular and widely used are following.

The Diffusion of Innovations (DOI) perspective is introduced by Rogers [85] investigating a variety of factors which are considered to be determinants for the actual adoption and usage of Information Systems. According to DOI, potential adopters evaluate an innovation based on innovation attributes (relative advantage, compatibility, complexity, trialability and observability) [85]. The Theory of Reasoned Action (TRA) was first proposed by Fishbein and Ajzen [33], suggesting that users' intention to adopt a technology is determined by two factors: personal in nature (attitude) and social influence (social or subjective norm). TRA was later evolved to the Theory of Planned Behavior (TPB) by adding perceived behavioral control to the initial determinants [4]. [4] has proved that perceived behavior control has a direct effect on behavior and desire through an empirical study, and proposed the Theory of Planned Behavior (TPB) based on the Theory of Reasoned Action (TRA). TPB emphasized the adopters' attitudes towards technology, expressed social influence factors via the subjective regulated variables, and expressed the adopters' personal characteristics via perceived behavior control. The TPB was also enriched with stable, decomposed beliefs structures for the TPB model and proposed the Decomposed Theory of Planned Behavior [88]. The Expectancy Confirmation Model (ECM) or the Expectancy Disconfirmation Model (EDM) has been used to explain the continuance behavior in electronic commerce. It is important for the $\mathrm{m}$-shopping providers to understand the determinants of m-shopping continuance [16], [49].

Furthermore, the Technology Acceptance Model (TAM) indicates that perceived ease of use and perceived usefulness are the two main beliefs that determine one's intention to use technology [26]. TAM has been the mostly constantly used or extended model regarding m-service adoption and m-shopping, comparing favorably to TRA and TPB [65], [86], [88], [108].

When deeper explanation of user adoption intention is desired, it allows other factors to be incorporated easily into its basic model [46]. Since the original proposal, TAM has been used and adapted extensively, and is seen as a leading model in explaining and predicting system use. In the context of mobile commerce, [107] used a revised TAM to explore the factors that determine user mobile commerce (including banking, shopping, investing, and online services) acceptance in Taiwan. They identified the following as factors affecting behavioral intention to use: perceived risk, cost, compatibility, and perceived usefulness. [104] used TAM, with the objective to predict consumer intention to use mobile services. [64] also used a revised TAM model to explore the factors affecting purchase intention on mobile shopping websites. Furthermore, [80] identified the availability of a mobile interface as a contributing factor to satisfaction with the online shopping experience. Additionally, [108] explored an integrative perspective, related to the adoption of mobile healthcare by hospital's professionals.

Finally, the Unified Theory of Acceptance and Use of Technology (UTAUT) combined eight models, based on the above theories plus a few of their extensions, in a unified technology acceptance concept. The proposed unified model contains five determinants: performance expectancy, effort expectancy, social influence, facilitating conditions, and behavioral intention [98]. It is used so far for a number of technology types such as e-government [6], wireless Local Area Network (LAN) [8] and m-commerce [110].

When deeper explanation of mobile consumer adoption intention is desired, TAM allows other factors to be incorporated easily into its basic model [46]. Hence, in the current study, we keep the basic variables of TAMperceived ease of use, perceived usefulness and behavioral intention-and through literature research we contribute with new variables-mobile skillfulness, enjoyment, anxiety, trust, innovativeness and relationship drivers-which are expected to have influence on the mobile shopping intention. All these constructs in this paper, are defined in a strict mobile context.

The rest of the paper is organized as follows: In the first section, the literature review regarding m-commerce adoption is presented. This is followed by an explanation of the hypotheses formed, based on literature review, and the description of the constructs that are included in the proposed model. In the third section a description of the applied methodology and the results of the empirical research are presented. The final section concludes with a discussion commenting on the data gathered and recommends some ideas for future research directions.

\section{Literature Review and Hypotheses Development}

A survey research is conducted using a questionnaire to examine the factors that affect the users' behavioral intention to adopt $m$-shopping. Based on the literature review, a conceptual model including the initial hypotheses is formulated (Figure 1). The model consists of the following variables: Behavioral Intention, Anxiety, Mobile Skillfulness, Perceived Usefulness, Perceived Ease of Use, Trust, Relationship Drivers, Innovativeness and Enjoyment. In this section, the variables are explained, and the related hypotheses are developed. 


\subsection{Behavioral Intention}

In most of the well-established models of behavioral intention theories, such as the Technology Adoption Model (TAM) and the Theory of Reasoned Action (TRA), there has been an attempt to examine the factors that affect the consumers' decision on using a technology studied [107]. [31] first defined the term Behavioral Intention to depict "a person's subjective probability that he will perform some behavior". [26], also, followed up with this idea to give shape to TAM, which finally concludes to the Actual System Use. Based on these concepts, in the paper herein, there is a construct included in the proposed model entitled Behavioral Intention to describe a person's subjective probability that he/ she will purchase online via a mobile device.

\subsection{Perceived Usefulness}

Perceived usefulness has been a fundamental construct in many of the technology adoption models that have been proposed since 1989, when Davis first used this term [26]. It has been widely utilized in m-commerce area of study as well. For example, [53], [57], [59], [70], [71] confirmed that perceived usefulness is positively related to $\mathrm{m}$ commerce behavioral intention. [5], [42], [90] proved that perceived usefulness positively affects mobile banking adoption and [53] confirmed that perceived usefulness affects mobile coupons adoption. Commonly, [115] confirmed that perceived usefulness positively impact on m-services' behavioral intention and [19] approved its effect on $\mathrm{m}$ payments. In this study, perceived usefulness refers to the degree which an individual believes that using a mobile device to shop online would enhance his/ her job performance. Thus, a mobile device with high perceived usefulness, sequentially, is one for which the m-user believes in the existence of a positive use-performance connection [26], [71]. Based on the aforementioned literature the following hypothesis can be stated:

\section{H1: Perceived usefulness has a positive effect on m-shopping behavioral intention.}

\subsection{Perceived Ease of Use}

Additionally to perceived usefulness, perceived ease of use has been a vital concept in many of technology adoption models regarding not only technologies and systems in general, but also m-shopping (e.g., [51], [92], [102]). For example, [24], [57], [71], [93] confirmed the significant impact of perceived ease of use on consumer's intention to adopt m-commerce. Additionally, [115] presented its positively impact on m-services' behavioral intention, [42], [66] and [103] its influence on m-banking adoption and [53] its influence on m-coupons adoption. However, a number of studies have confirmed that perceived ease of use can also indirectly impact behavioral intention through perceived usefulness. On these studies, researchers have proposed adoption intention models where perceived ease of use strongly impact on perceived usefulness. These investigations include a variety of mobile technology topics, such as m-commerce [7], [92], [106] and mobile data services [82], [115]. Furthermore, many researchers argued that perceived ease of use is not only considered as important factor for the adoption of a technology, but it affects longterm use of a technology as well [39], [50], [84]. Hence, it is a vital concern to examine the role of this construct to mshopping.

Based on the aforementioned literature, the following hypotheses can be stated:

H2: Perceived ease of use has a positive effect on m-shopping behavioral intention.

H3: Perceived ease of use has a positive effect on perceived usefulness.

\subsection{Anxiety}

Several researchers have investigated anxiety as a significant inhibitor of IT and m-shopping adoption (e.g., [11], [12], [47], [64], [67]). Consumer anxiety about using IT focuses on individual's ability and willingness to use technologyrelated tools [67]. Regarding m-commerce, according to [111], due to its newness and uniqueness in shopping encounters, m-commerce might provoke users' anxiety to m-shopping adoption. [12] proved that anxiety impacts negatively on perceived ease of use of $\mathrm{m}$-payments. Considering that $\mathrm{m}$-commerce consists of data services that are not limited by temporal and spatial boundaries, consumer anxiety about using $m$-shopping is expected to exist and may be higher than anxiety about other shopping methods [111]. For example, while e-commerce demands a specific fixed local area network to access a website, m-commerce can be done everywhere via data services [44]. Furthermore, [11] mentioned that consumer anxiety about using data services is higher in the mobile environment because the responsibility for a failure or loss of a transaction may not be clear in this technology-mediated environment. [47] emphasized that anxiety increases since m-users are sensitive to services related to monetary transactions where they may lose both money and personal information. Taking into consideration the extremely personalized nature of mobile devices, it goes without saying that there is an increase in privacy and security concerns. Unfortunately, even skilled $\mathrm{m}$-users may be frustrated while using $\mathrm{m}$-commerce services because so many options have been placed into such a tiny device, and these "new capabilities often negatively affect users' experience on other dimensions" [52] p. 7. As a consequence, individuals who are less anxious about using $\mathrm{m}$ - 
shopping also feel more comfortable utilizing it; so they are more likely to adopt $\mathrm{m}$-commerce services. The volume of potential m-transactions is definitely expected to be higher in less anxious mobile users as well. Additionally, the more anxious the potential $\mathrm{m}$-shopper is, the less easy its interaction with a mobile device for a monetary transaction will be. Thus, it is reasonably expected that he/ she will find it more difficult to shop via a mobile device than a free of anxiety individual. A stressful state of mind can undeniably disturb the easiness of $\mathrm{m}$-shopping.

In this study, anxiety refers to negative emotions in cognitive states which evoked in actual or imaginary monetary online transactions via a mobile device [64]. Therefore, it is a vital concern to examine the role that negative emotional response plays in whether or not to adopt $m$-shopping.

Based on the aforementioned literature, the following hypotheses can be stated:

H4: Anxiety has a negative effect on m-shopping behavioral intention.

H5: Anxiety has a negative effect on perceived ease of use.

\subsection{Mobile Skillfulness}

Several studies have investigated skillfulness as a significant factor in influencing consumers' behavior towards a specific technology (e.g., [25], [31]). Therefore, it is strongly recommended that skillfulness should also be examined as a driving factor in the area of mobile commerce (e.g., [64]). In this study, skillfulness refers to the individual's assessment of his/ her ability to purchase online via a mobile device. It is assumed that the greater m-user's capability belief the greater the chances to adopt and use mobile devices to shop online. For example, various studies found that the greater the user's capability belief the greater user's intrinsic motivation [22], [29], [64]. On the contrary, other researches have confirmed that people feel anxiety in their attempt to achieve particular behaviors that they do not perform skillfully [64]. Therefore, individual's emotional arousal anxiety has been approved to negatively impact on his/ her perceived capability [22], [31], [64]. Furthermore, it is considered as important to understand the potential impact of mobile skillfulness to perceived enjoyment and perceived usefulness as well [9]. In specific, it is alleged that the greater the user's capability belief the greater user's gratification of $m$-shopping experience. Additionally, his/ her capability belief is expected to positively impact on perceived usefulness. Characteristically, [64] found that consumers' lack of self-perception of mobile skillfulness can significantly reduce perceptions of enjoyment and usefulness. However, as far as it is concerned, both aforementioned factors have been slightly investigated by the academia regarding the m-commerce area of interest. Thus, based on the aforementioned literature, the following hypotheses can be stated:

H6: Mobile skillfulness has a positive effect on m-shopping behavioral intention.

H7: Mobile skillfulness has a negative effect on anxiety.

H8: Mobile skillfulness has a positive effect on perceived enjoyment.

H9: Mobile skillfulness has a positive effect on perceived usefulness.

\subsection{Trust}

In order to define and measure trust, there have been many suggestions in literature attributing it to meanings like privacy protection permitting a user to choose how his or her personal information is used [16], or perceived credibility showing that one partner believes that the other partner has the required expertise to perform a job effectively and reliably [20], [23]. [78] stated that trust in e-commerce is the belief that allows consumers to willingly become vulnerable to the online retailers after having considered the retailers' characteristics including goodwill trust (benevolence) and credibility (honesty, reliability, and integrity). [70] divided the entity of trust in two sub-entities: trust in technology and trust in service providers. Trust in technology redirects to technical protocols, transaction standards, regulating policies, and payment systems [70], whereas, according to [16] analysis for e-commerce services, trust in service providers refers to ability -the user's perception of provider's competencies and knowledge salient to the expected behaviour, integrity -the user's perception that the service providers will adhere to a set of principles or rules of exchange acceptable to the users during and after the exchange, and benevolence -the service provider is believed to intend doing good to the users, beyond its own profit motive.

In this study, the factor of trust refers to a) the security of mobile payments while shopping, b) the confidentiality of personal data (such as respecting consumers' credit card details), c) the trustworthiness in the results after mobile purchases are conducted, and d) the full compliance with the terms \& conditions of each mobile shop.

[70], [109] studying mobile commerce, [78] examining consumers' acceptance of electronic commerce, [42], [90] investigating m-banking adoption, [21], [106] analyzing the m-commerce adoption, [91] contributing to e-banking, and [37] talking about Business-to-Customer (B2C) e-Services detected a positive influence of trust on consumers' behavioral intention. In specific, [78] said that: trust reduces behavioral uncertainty related to the actions of the Web 
retailer, giving a consumer a perception of some control over a potentially uncertain transaction. On the other hand, [40] proved that there is an influence of trust on intention to e-shop through its influence on usefulness. This sense of overall control over their online transactions positively influences consumers' purchase intentions. Thus, it is reasonable to assume that there is, also, a positive relationship between trust and behavioral intention when it comes to the adoption of mobile shopping. So the following hypotheses can be stated:

\section{H10: Trust has a positive effect on mobile shopping behavioral intention.}

\section{H11: Trust has a positive effect on mobile shopping perceived usefulness.}

H12: Trust has a positive effect on mobile shopping perceived ease of use.

\subsection{Relationship Drivers}

[72] since 2000 has pointed out that one of the rules for a customer to feel closely related to a firm, or brand, or a process is the existence of distinctive competencies. Hence, we need to examine whether the distinctive competencies of the mobile shopping process cater to the specific interests and needs of the customers and lead to the development of solid relationships with them.

Experts in the marketing field have recognized some unique features of the mobile technology, which can help with the relationship building between the customers and the brand. To start with, the functions of SMS and MMS exchange give the mobile services the exclusiveness of ubiquitous and universal information accessibility, of information personalization and information dissemination [77]. [115] also mention that mobile and wireless technology do not set information access restrictions regarding time and space [13]. Mobile services' location and time personalization feature enables individuals to ask for directions to the nearest gas station while traveling, or can receive last-minute alerts and flight delay notices through their mobile devices.

The fact that consumers can reach the information and use the applications from everywhere [77], [80] and anytime [58], [78], [114], gives a strong advantage for time-sensitive and location-based content and services to be received on consumers' mobile devices at the point accustomed to their personal identity [30], [58], [77], [105]. Thus, personalized information and/or services are able to be achieved. [87] examining the success factors of mobile marketing, highlight 'personalization' as the key feature of mobility that drives consumers to shop. This statement is strongly reasoned, as they present scenarios, like the SMS advertising campaigns, which can be well-targeted to categorized groups, according to customers' profiles and their previous actions, e.g. past leisure activities, music interests, or occupation (preferential treatment).

Also, it gets quite common for the brands to prefer a mobile application as their sales channel instead of a physical or an online store, as they can be in the customers' hands anytime [79]. [87] concludes that a successful mobile advertising practice is based on the fact that some common mobile applications urge the recipients to act on the spot. For example, proximity marketing through Bluetooth (mainly in the past), or applications, which use iBeacons to transmit marketing content- e.g special discounts and coupons- to passers by, are common scenarios that trigger consumers and drive them to proceed with a purchase.

Additionally, mobile couponing is a common marketing strategy to increase mobile transactions [1], [76]. Mobile coupons can be delivered directly to the mobile device, e.g via an SMS and are stored in the mobile phone's memory, or even to dedicated mobile applications (e.g. Apple Wallet). Hence, they are hard to get lost or forgotten, and can be easily redeemed. If consumers are subject to get rewarded with mobile coupons, discount prices, prizes, newsletters, free call time, etc. when they participate in a mobile transaction, they would be motivated to use the mobile services more frequently [9].

All the above features are used to drive the user to a close relationship with the mobile services as they make the shopping experience meaningful and increase engagement with mobile transactions. Hence, the user integrates them in his daily activities, gets attached to them, and spends a lot of time conducting such services. We hypothesize that such relationship drivers affect individuals' mobile shopping intention, as well as mobile shopping perceived usefulness.

H13: Relationship Drivers have a positive effect on mobile shopping behavioral intention.

H14: Relationship Drivers have a positive effect on perceived usefulness of mobile shopping.

\subsection{Enjoyment}

Traditionally shopping is classified among the activities of fun and pleasure that leads to feelings of joy [55]. The retail literature has also focused on the notion of excitement [100]. However, [43] trying to define enjoyment claim that excitement corresponds to an emotional state that elicits high levels of pleasure and arousal, whereas 
enjoyment refers to a less emotional motivation correlated with consumers' logic, which lets them decide their likings while shopping.

Non-store formats of shopping can offer satisfaction to profiles of shoppers who are internet literate and technology fans. Those types of consumers can correlate the shopping process with a shopping channel, which is both easy for them, as well as offers them pleasure. That is the reason that enjoyment has been found to be a factor with a positive impact on online shopping intention [83], [95]. Also, [64] in their study verify their hypothesis that enjoyment is a consumer's intrinsic motivation that strongly affects the intention to engage in mobile shopping. [60] in their model verified that there is a significant effect of perceived post adoption enjoyment on the continued adoption of mobile services.

Additionally, apart from the studies that verify the direct effect of enjoyment on the intention to use factor of the TAM model, there are analyses that prove the correlation between enjoyment and perceived usefulness and perceived ease of use. To be more specific, [60] verify that if SMS services are perceived as enjoyable, the value perception of SMS as useful and easy to be used is increased. Also, [96] conducted a study in Singapore proving that perceived enjoyment is a significant predictor of perceived usefulness, perceived ease of use, and intention to use technology. Anyway, [27] observed the positive interaction between enjoyment and perceived usefulness, while studying the motivations to use computers in the workplaces.

\section{H15: Enjoyment has a positive effect on mobile shopping behavioral intention.}

H16: Enjoyment has a positive effect on perceived usefulness of mobile shopping.

H17: Enjoyment has a positive effect on perceived ease of use of mobile shopping.

\subsection{Innovativeness}

Innovativeness as a factor has been integrated in many previous technology acceptance studies. In information technology terminology innovativeness is used as the "willingness of an individual to try out any new information technology" [34], [69]. In free interpretation in the field of technology acceptance, innovation refers to the degree of interest in trying a new thing, new concept, or innovative product or service [85]. [2] first introduced innovativeness construct and its impact on information technology in 1998. Individuals, who are considered as competent technically by their social environment, tend to find that using new technology is less troublesome suggesting a direct positive effect of innovativeness on perceived ease of use [113].

There are more frameworks verifying this impact of innovativeness on both factors: behavioral intention and perceived ease of use. To be more specific, [101] concluded that innovativeness has a positive impact on perceived ease of use and negative impact on perceived usefulness regarding the adoption process of IT from service employees. The study by [63] showed that innovativeness has a positive impact on perceived ease of use of $3 G$ mobile value-added services, whereas the influence on perceived usefulness of $3 \mathrm{G}$ mobile value-added services is insignificant. Additionally, [57] confirmed that innovativeness impact positively on perceived ease of use of $\mathrm{m}$ commerce. [18] discussed the importance of innovation for the mobile telecom industry, as well as, [3] confirmed the positive impact of personal innovativeness on behavioral intention to use mobile services in libraries. Furthermore, [56] showed that innovativeness has a positive effect on both perceived ease of use and continuance intention to use m-commerce.

The positive results of studies around the direct effect of innovativeness on mobile commerce [65], [110] and on mobile shopping [7] lead the authors to hypothesize that:

H18: Innovativeness has a positive effect on mobile shopping behavioral intention.

H19: Innovativeness has a positive effect on perceived ease of use of mobile shopping.

All the hypotheses formed above, are summarized in Table 1. 


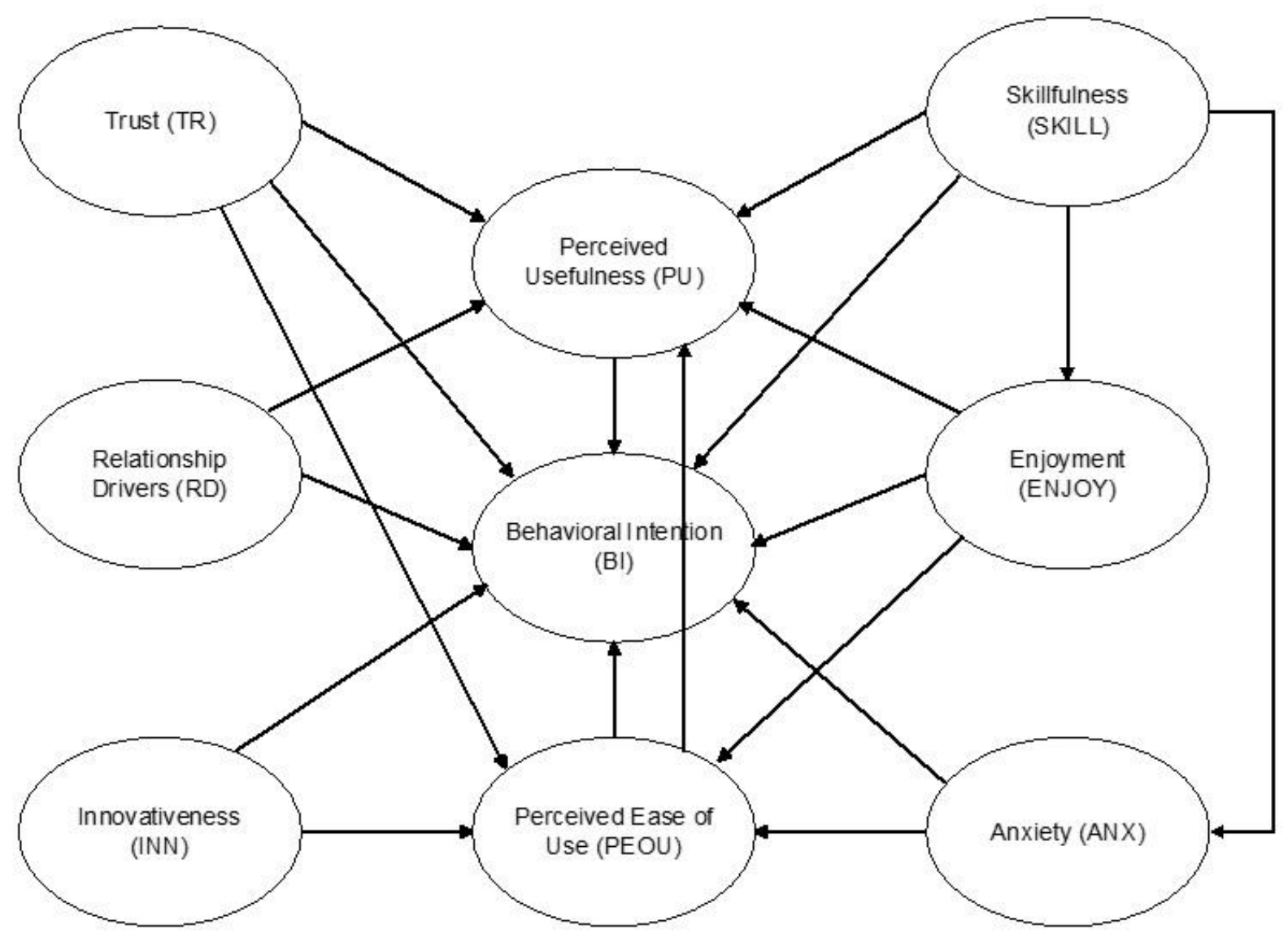

Figure 1: Hypothesized model (Model 1)

\section{Methodology}

This section presents the methodological approach adopted in the current study. In specific, operational definitions of the study variables are provided and the study procedure (data collection and sample characteristics) is presented. The section concludes with a description of the structural equation modeling framework used for analyzing the data.

\subsection{Operationalization of Variables}

Operational definitions of the study variables are shown in Table 2. For each variable, a multiple-item scale was developed based on literature review; where each item was measured based on a 5-point Likert scale, ranging from 1-Completely Disagree to 5-Completely Agree. Three items were used to measure anxiety, skillfulness and enjoyment, four items were used to measure perceived ease of use, trust, innovativeness, relationship drivers and behavioral intention, whereas five items were used to measure perceived usefulness.

\subsection{Data Collection and Sample Characteristics}

Data were collected through a structured electronic questionnaire which was uploaded on a website for three month, from February to April 2016. Additionally, contacts from various mailing lists were asked to fill in the questionnaire, as well as members of two popular social networks-Facebook and Twitter-were encouraged to participate in the survey. The questionnaire was based on prior surveys approved for their validity and reliability and was pretested before being widely distributed. A pilot study using a sample of thirty responses helped to identify possible problems in terms of clarity and accuracy Thus, comments and feedback from respondents improved the final presentation of the items. Thirty two participants gave incomplete answers and their results were dropped from the study. As a result, the final sample consisted of 473 respondents. 
Table 1: Research hypotheses in the current study

\begin{tabular}{|c|c|c|}
\hline Hypothesis & Description & Path \\
\hline $\mathrm{H} 1$ & Perceived usefulness has a positive effect on m-shopping behavioral intention. & $\mathrm{PU} \rightarrow \mathrm{BI}$ \\
\hline $\mathrm{H} 2$ & Perceived ease of use has a positive effect on m-shopping behavioral intention. & $\mathrm{PEOU} \rightarrow \mathrm{BI}$ \\
\hline H3 & Perceived ease of use has a positive effect on perceived usefulness. & $\begin{array}{l}\mathrm{PEOU} \rightarrow \\
\mathrm{PU}\end{array}$ \\
\hline $\mathrm{H} 4$ & Anxiety has a negative effect on m-shopping behavioral intention. & $\mathrm{ANX} \rightarrow \mathrm{BI}$ \\
\hline H5 & Anxiety has a negative effect on perceived ease of use. & $\begin{array}{l}\text { ANX } \rightarrow \\
\text { PEOU }\end{array}$ \\
\hline $\mathrm{H} 6$ & Mobile skillfulness has a positive effect on m-shopping behavioral intention. & $\mathrm{SKL} \rightarrow \mathrm{BI}$ \\
\hline $\mathrm{H} 7$ & Mobile skillfulness has a negative effect on anxiety. & $\mathrm{SKL} \rightarrow \mathrm{ANX}$ \\
\hline H8 & Mobile skillfulness has a positive effect on perceived enjoyment. & $\mathrm{SKL} \rightarrow \mathrm{ENJ}$ \\
\hline H9 & Mobile skillfulness has a positive effect on perceived usefulness. & $\mathrm{SKL} \rightarrow \mathrm{PU}$ \\
\hline $\mathrm{H} 10$ & Trust has a positive effect on mobile shopping behavioral intention. & $\mathrm{TR} \rightarrow \mathrm{BI}$ \\
\hline $\mathrm{H} 11$ & Trust has a positive effect on mobile shopping perceived usefulness. & $\mathrm{TR} \rightarrow \mathrm{PU}$ \\
\hline $\mathrm{H} 12$ & Trust has a positive effect on mobile shopping perceived ease of use. & $\begin{array}{l}\text { TR } \rightarrow \\
\text { PEOU }\end{array}$ \\
\hline $\mathrm{H} 13$ & $\begin{array}{l}\text { Relationship Drivers have a positive effect on mobile shopping behavioral } \\
\text { intention. }\end{array}$ & $\mathrm{RD} \rightarrow \mathrm{BI}$ \\
\hline $\mathrm{H} 14$ & $\begin{array}{l}\text { Relationship Drivers have a positive effect on perceived usefulness of mobile } \\
\text { shopping. }\end{array}$ & $\mathrm{RD} \rightarrow \mathrm{PU}$ \\
\hline $\mathrm{H} 15$ & Enjoyment has a positive effect on mobile shopping behavioral intention. & $\mathrm{ENJ} \rightarrow \mathrm{BI}$ \\
\hline $\mathrm{H} 16$ & Enjoyment has a positive effect on perceived usefulness of mobile shopping. & $\mathrm{ENJ} \rightarrow \mathrm{PU}$ \\
\hline $\mathrm{H} 17$ & Enjoyment has a positive effect on perceived ease of use of mobile shopping. & $\begin{array}{l}\text { ENJ } \rightarrow \\
\text { PEOU }\end{array}$ \\
\hline $\mathrm{H} 18$ & Innovativeness has a positive effect on mobile shopping behavioral intention. & INN $\rightarrow \mathrm{BI}$ \\
\hline $\mathrm{H} 19$ & $\begin{array}{l}\text { Innovativeness has a positive effect on perceived ease of use of mobile } \\
\text { shopping. }\end{array}$ & $\begin{array}{l}\text { INN } \rightarrow \\
\text { PEOU }\end{array}$ \\
\hline
\end{tabular}

Table 2: The operational definition of research variables

\begin{tabular}{|l|l|}
\hline \multicolumn{1}{|c|}{ Research variables } & \multicolumn{1}{c|}{ Operational definition } \\
\hline \multirow{4}{*}{ Behavioral Intention (BI) } & BI1: I intend to buy via mobile devices in the near future \\
\cline { 2 - 3 } & BI2: I believe my interest towards m-shopping will increase in the future \\
\cline { 2 - 3 } Perceived Usefulness (PU) & BI3: I intend to buy via mobile devices as much as possible \\
\cline { 2 - 3 } & BI4: I recommend others to utilize m-shopping \\
\hline & PU1: I think you save time when you buy via mobile devices \\
\cline { 2 - 3 } Perceived Ease & PU2: I think buying via mobile devices would increase my effectiveness \\
\cline { 2 - 3 } of Use (PEOU) & PU3: I think buying products and services via mobile devices is cheaper \\
\cline { 2 - 3 } & PU4: I think buying via mobile devices would increase my usability \\
\cline { 2 - 3 } & PU5: I think buying via mobile devices would increase my productivity \\
\hline & PEU1: I think buying via mobile devices would be easy \\
\cline { 2 - 3 } & PEU2: I think learning to buy via mobile devices would be easy \\
\cline { 2 - 3 } & PEU3: I think finding what I want via m-shopping would be easy \\
\cline { 2 - 3 } & PEU4: I think becoming skillful at using mobile devices to shop online. \\
\hline
\end{tabular}




\begin{tabular}{|c|c|}
\hline \multicolumn{2}{|l|}{ Table 2: continuation } \\
\hline \multirow{4}{*}{ Trust (TR) } & TR1: I feel monetary transactions in mobile shopping is safe \\
\hline & TR2: I feel my personal data are in confidence in mobile shopping \\
\hline & $\begin{array}{l}\text { TR3: I feel the terms of use are strictly followed while buying via mobile } \\
\text { devices }\end{array}$ \\
\hline & $\begin{array}{l}\text { TR4: I feel mobile shopping transactions' outcome is closed to my } \\
\text { expectations }\end{array}$ \\
\hline \multirow{4}{*}{ Innovativeness (INN) } & INN1: I am usually among the first to try m-services to buy online \\
\hline & INN2: I am eager to learn about new technologies \\
\hline & INN3: I am eager to try new technologies \\
\hline & $\begin{array}{l}\text { INN4: My friends and neighbours often come to me for advice about new } \\
\text { technologies and innovation }\end{array}$ \\
\hline \multirow{4}{*}{$\begin{array}{l}\text { Relationship } \\
\text { Drivers (RD) }\end{array}$} & $\begin{array}{l}\text { RD1: I think that the loyalty points reward from shopping via mobile } \\
\text { devices is important to me }\end{array}$ \\
\hline & $\begin{array}{l}\text { RD2: I think that the availability to coupons' redemption from shopping via } \\
\text { mobile devices is important to me }\end{array}$ \\
\hline & $\begin{array}{l}\text { RD3: I think that special offers provided only to online purchases via } \\
\text { mobile devices are important to me }\end{array}$ \\
\hline & $\begin{array}{l}\text { RD4: I think that mobile shopping notifications customized to the location } \\
\text { and time I am, are important to me }\end{array}$ \\
\hline \multirow{3}{*}{ Skillfulness (SKILL) } & $\begin{array}{l}\text { SKL1: I feel confident using a mobile device to buy online a product/ } \\
\text { service efficiently }\end{array}$ \\
\hline & $\begin{array}{l}\text { SKL2: I think that I would be able to buy a product/ service via a mobile } \\
\text { device in a short time if I had some hints }\end{array}$ \\
\hline & $\begin{array}{l}\text { SKL3: I think I would be able to buy a product/ service via a mobile device } \\
\text { in a short time if I had a similar experience before }\end{array}$ \\
\hline \multirow{3}{*}{ Enjoyment (ENJOY) } & ENJOY1: I think buying via mobile devices is enjoyable \\
\hline & ENJOY2: I think buying via mobile devices is a pleasure process \\
\hline & ENJOY3: I think buying via mobile devices is fun \\
\hline \multirow{3}{*}{ Anxiety (ANX) } & ANX1: I feel apprehensive about using mobile devices to shop online \\
\hline & $\begin{array}{l}\text { ANX2: I hesitate to use mobile devices to shop online for fear of making } \\
\text { mistakes }\end{array}$ \\
\hline & $\begin{array}{l}\text { ANX3: Using mobile devices to shop online is somewhat intimidating to } \\
\text { me }\end{array}$ \\
\hline
\end{tabular}

The demographic profile of the respondents, presented in Table 3, indicates that $49.3 \%$ were male and $50.7 \%$ female. The vast majority $(87.7 \%)$ was between $18-34$ years old, whereas only $2.7 \%$ was above the age of 44 . In terms of their educational background, about $80 \%$ had received a higher education degree, whereas with respect to their occupation more than half $(54 \%)$ were students, followed by private employees $(21.6 \%)$ and public servants $(8.9 \%)$. Finally, the majority of respondents reported a monthly income less than $900 €$, whereas about one out of four $(26 \%)$ did not reveal their income. 


\subsection{Data Analysis Plan}

Structural equation modeling (SEM) using maximum likelihood estimation was used to test the hypothesized model of Figure 1. SEM is appropriate to test hypothesized structural relations between multiple independent and dependent variables (through the use of estimated regression parameters). Although the use of SEM in crosssectional designs cannot lead to establishing causal pathways, it is useful for testing the relative fit of a given causal model to an existing data set. SEM is comprised of a measurement model and a structural model.

The measurement part of the model allows for the estimation of latent variables reflecting constructs of interest. The measurement model for all nine constructs was first assessed using Confirmatory Factor Analysis (CFA). CFA assumes each manifest variable to be a distinct indicator of an underlying latent construct, whereby different constructs are permitted to be inter-correlated. Further, reliability, convergent and discriminant validity of the constructs were evaluated. Convergent validity uses three recommended standards to assess the measuring model: (1) all indicator factor loading values should exceed 0.5 [41]; (2) composite reliability (CR) should exceed 0.6 [10]; and (3) the average variance extracted (AVE) of each construct should exceed 0.5 [35]. Discriminant validity was also assessed by comparing the correlations between constructs with the square roots of AVE values [35]. In order to detect common method bias, post hoc Harman's one factor analysis was conducted to check whether variance in the data can be largely attributed to a single factor [81].

After the constructs have met the required measurement standards, the relationships between the constructs were estimated. This constitutes the structural model, which is tested to investigate the strength and direction of the relationships between the theoretical constructs. A model's overall goodness-of-fit can be assessed using a combination of measures. The basis for an adequately fitted model was a chi-square/df ratio less than five [15], adjusted goodness-of-fit index (AGFI), comparative fit index (CFI), normed fit index (NFI), incremental fit index (IFI) and Tucker-Lewis index (TLI) values greater than 0.90 [48], a root mean square error of approximation (RMSEA) less than 0.05 [17] and a standardized root-mean square residual (SRMR) less than 0.08 [48]. The stability of the model estimates was tested via a bootstrap resampling procedure (500 sub-samples). All SEM analyses were conducted in Mplus version 7.31 [73].

Table 3: Demographic characteristics of the study participants $(n=473)$

\begin{tabular}{|c|c|c|c|}
\hline Demographics & & Frequency & Percent (\%) \\
\hline \multirow[t]{2}{*}{ Gender } & Male & 233 & 49.3 \\
\hline & Female & 240 & 50.7 \\
\hline \multirow[t]{4}{*}{ Age } & $18-24$ & 236 & 49.9 \\
\hline & $25-34$ & 179 & 37.8 \\
\hline & $35-44$ & 45 & 9.5 \\
\hline & $>44$ & 13 & 2.7 \\
\hline \multirow[t]{4}{*}{ Education } & Elementary school & 3 & 0.6 \\
\hline & High school & 97 & 20.5 \\
\hline & University/Tech. Col. & 279 & 59.0 \\
\hline & Master/PhD & 94 & 19.0 \\
\hline \multirow[t]{6}{*}{ Occupation } & Student & 256 & 54.1 \\
\hline & Private Employee & 102 & 21.6 \\
\hline & Public Servant & 42 & 8.9 \\
\hline & Freelancer & 34 & 7.2 \\
\hline & Unemployed & 25 & 5.3 \\
\hline & Other & 14 & 3.0 \\
\hline \multirow[t]{7}{*}{ Monthly Income $(€)$} & $<600$ & 198 & 41.9 \\
\hline & $601-900$ & 59 & 12.5 \\
\hline & $901-1200$ & 39 & 8.2 \\
\hline & $1201-1500$ & 32 & 6.8 \\
\hline & $1501-2000$ & 6 & 1.3 \\
\hline & $>2000$ & 16 & 3.4 \\
\hline & No answer & 123 & 26.0 \\
\hline
\end{tabular}

\section{Results}

This section summarizes the results of the SEM framework used to empirically test the hypothesized relationships among the study variables. The measurement part of the model is first developed and tested, followed by the evaluation of the structural model. 


\subsection{Measurement Model}

The measurement model (i.e. Confirmatory Factor Analysis or CFA model) included 34 items describing the nine latent constructs presented in Table 3. The model's overall goodness-of-fit was satisfactory (Table 4): chi square/df, Standardized Root Mean Square Residual (SRMR), and (Root Mean Square Error of Approximation) RMSEA are less than the recommended values while Goodness of Fit Index (GFI), Adjusted Goodness of Fit (AGFI), Comparative Fit Index (CFI), Normed Fit Index (NFI), Incremental Fit Index (IFI) and Tucker-Lewis Index (TLI) are greater than the suggested threshold. The standardized indicator factor loadings for all observed indicators, shown in Table 5, were all statistically significant and exceeded 0.5 . Skewness and kurtosis values for all items were less than three, which revealed no significant departures from normality [61]. Composite reliability (CR) of constructs ranged from 0.76 to 0.95 , above the recommended threshold of 0.6 . Cronbach's alpha values were also high in all cases $(>0.80)$. Average variance extracted (AVE) values were greater than the recommended 0.5 cut-off, ranging from 0.51 to 0.86 . Therefore, all the conditions for convergent validity were met. Table 6 shows that the the square roots of AVE were all greater than the inter-scale correlations (off-diagonal elements) in the corresponding rows and columns, and therefore, discriminant validity was supported. Furthermore, an un-rotated principal component factor analysis revealed nine factors with eigenvalues greater than 1 . The first factor accounted for $29.7 \%$ of covariance among the measures at maximum. The other eight factors contributed $37.5 \%$ of the remaining variance, each accounting for $3-$ $8 \%$. Thus, common method bias is not likely a contaminant of our results. In addition, an inspection of modification indices did not suggest any model revisions that were substantially meaningful.

Table 4: Evaluation of model goodness-of-fit

\begin{tabular}{|l|l|l|l|}
\hline Measures & Recommended value & Measurement model & Structural model \\
\hline $\mathrm{X}^{2} / \mathrm{df}$ & $\leq 5.00^{\mathrm{a}}$ & 2.14 & 2.34 \\
\hline $\mathrm{GFI}$ & $\geq 0.90^{\mathrm{b}}$ & 0.97 & 0.96 \\
\hline $\mathrm{AGFI}$ & $\geq 0.90^{\mathrm{b}}$ & 0.96 & 0.96 \\
\hline $\mathrm{CFI}$ & $\geq 0.90^{\mathrm{b}}$ & 0.97 & 0.96 \\
\hline $\mathrm{NFI}$ & $\geq 0.90^{\mathrm{b}}$ & 0.94 & 0.94 \\
\hline IFI & $\geq 0.90^{\mathrm{b}}$ & 0.94 & 0.94 \\
\hline TLI & $\geq 0.90^{\mathrm{b}}$ & 0.96 & 0.96 \\
\hline $\begin{array}{l}\mathrm{RMSEA} \\
{[90 \% \mathrm{Cl}]}\end{array}$ & $\leq 0.05^{\mathrm{c}}$ & 0.045 & 0.049 \\
\hline SRMR & $\leq 0.08^{\mathrm{b}}$ & {$[0.041-0.049]$} & {$[0.045-0.053]$} \\
\hline a[15], ${ }^{\mathrm{c}}[17],{ }^{\mathrm{b}}[48]$ & 0.061 & 0.066 \\
\hline
\end{tabular}

Table 5: Standardized factor loadings and individual item reliability

\begin{tabular}{|c|c|c|c|c|c|c|c|}
\hline Construct & Item & Loading & Skewness & Kurtosis & $\mathrm{CR}$ & AVE & Cronbach's a \\
\hline \multirow{5}{*}{$\begin{array}{l}\text { Perceived Usefulness } \\
\text { (PU) }\end{array}$} & 1 & 0.678 & -0.60 & -0.28 & \multirow[t]{4}{*}{0.84} & 0.51 & \multirow[t]{5}{*}{0.82} \\
\hline & 2 & 0.706 & -0.01 & 0.25 & & & \\
\hline & 3 & 0.715 & -0.05 & -0.68 & & & \\
\hline & 4 & 0.821 & -0.33 & -0.46 & & & \\
\hline & 5 & 0.635 & 0.02 & 0.03 & & & \\
\hline \multirow{4}{*}{$\begin{array}{l}\text { Behavioral } \\
\text { Intention } \\
\text { (BI) }\end{array}$} & 1 & 0.828 & -0.48 & 0.09 & \multirow[t]{4}{*}{0.89} & 0.67 & \multirow[t]{4}{*}{0.89} \\
\hline & 2 & 0.734 & -0.60 & 0.16 & & & \\
\hline & 3 & 0.834 & 0.12 & -0.37 & & & \\
\hline & 4 & 0.885 & -0.08 & -0.60 & & & \\
\hline \multirow{4}{*}{$\begin{array}{l}\text { Perceived Ease } \\
\text { Of Use } \\
\text { (PEOU) }\end{array}$} & 1 & 0.801 & -0.48 & 0.39 & \multirow[t]{4}{*}{0.81} & 0.51 & \multirow[t]{4}{*}{0.80} \\
\hline & 2 & 0.690 & -0.76 & 1.17 & & & \\
\hline & 3 & 0.697 & -0.50 & 0.03 & & & \\
\hline & 4 & 0.661 & -0.76 & 1.08 & & & \\
\hline
\end{tabular}




\begin{tabular}{|c|c|c|c|c|c|c|c|}
\hline \multirow{4}{*}{$\begin{array}{l}\text { Trust } \\
\text { (TR) }\end{array}$} & 1 & 0.847 & -0.18 & -0.10 & \multirow[t]{4}{*}{0.82} & 0.60 & \multirow[t]{4}{*}{0.86} \\
\hline & 2 & 0.841 & -0.19 & -0.10 & & & \\
\hline & 3 & 0.683 & -0.25 & 0.47 & & & \\
\hline & 4 & 0.530 & -0.53 & 0.91 & & & \\
\hline \multirow{4}{*}{$\begin{array}{l}\text { Relationship } \\
\text { Drivers } \\
\text { (RD) }\end{array}$} & 1 & 0.761 & -0.58 & -0.31 & \multirow[t]{4}{*}{0.82} & 0.59 & \multirow[t]{4}{*}{0.82} \\
\hline & 2 & 0.869 & -0.81 & 0.37 & & & \\
\hline & 3 & 0.732 & -0.92 & 0.89 & & & \\
\hline & 4 & 0.521 & -0.30 & -0.77 & & & \\
\hline \multirow[t]{4}{*}{ Innovativeness (INN) } & 1 & 0.748 & 0.19 & -1.02 & \multirow[t]{4}{*}{0.76} & 0.52 & \multirow[t]{4}{*}{0.84} \\
\hline & 2 & 0.738 & -1.26 & 2.27 & & & \\
\hline & 3 & 0.664 & -0.90 & 0.60 & & & \\
\hline & 4 & 0.583 & -0.58 & -0.64 & & & \\
\hline \multirow{3}{*}{$\begin{array}{l}\text { Skillfulness } \\
\text { (SKILL) }\end{array}$} & 1 & 0.834 & -0.37 & -0.28 & \multirow[t]{3}{*}{0.80} & 0.58 & \multirow[t]{3}{*}{0.81} \\
\hline & 2 & 0.766 & -0.91 & 0.65 & & & \\
\hline & 3 & 0.674 & -1.38 & 2.64 & & & \\
\hline \multirow[t]{3}{*}{ Enjoyment (ENJOY) } & 1 & 0.973 & -0.19 & -0.69 & \multirow[t]{3}{*}{0.95} & 0.86 & \multirow[t]{3}{*}{0.94} \\
\hline & 2 & 0.918 & -0.31 & -0.72 & & & \\
\hline & 3 & 0.892 & -0.30 & -0.78 & & & \\
\hline \multirow{3}{*}{$\begin{array}{l}\text { Anxiety } \\
\text { (ANX) }\end{array}$} & 1 & 0.895 & -0.31 & -0.97 & \multirow[t]{3}{*}{0.90} & 0.74 & \multirow[t]{3}{*}{0.89} \\
\hline & 2 & 0.822 & 0.10 & -1.21 & & & \\
\hline & 3 & 0.850 & 0.06 & -1.11 & & & \\
\hline
\end{tabular}

Table 6: Inter-correlations and square roots of average variance extracted

\begin{tabular}{|l|l|l|l|l|l|l|l|l|l|}
\hline & 1 & 2 & 3 & 4 & 5 & 6 & 7 & 8 & 9 \\
\hline PEOU (1) & 0.67 & & & & & & & & \\
\hline PU (2) & 0.45 & 0.67 & & & & & & & \\
\hline BI (3) & 0.44 & 0.53 & 0.82 & & & & & & \\
\hline TR (4) & 0.38 & 0.29 & 0.43 & 0.77 & & & & & \\
\hline RD (5) & 0.19 & 0.34 & 0.44 & 0.27 & 0.77 & & & & \\
\hline INN (6) & 0.37 & 0.25 & 0.56 & 0.42 & 0.31 & 0.68 & & & \\
\hline SKL (7) & 0.39 & 0.27 & 0.38 & 0.41 & 0.22 & 0.44 & 0.64 & & \\
\hline ENJ (8) & 0.39 & 0.52 & 0.57 & 0.33 & 0.38 & 0.38 & 0.26 & 0.93 & \\
\hline ANX (9) & -0.45 & -0.30 & -0.43 & -0.49 & -0.16 & -0.47 & -0.36 & -0.35 & 0.86 \\
\hline
\end{tabular}

Note: The diagonal elements show the square root of the average variance extracted. The of diagonal elements show the correlations between the constructs, all significant at 0.01 level.

\subsection{Structural Model}

Once the measurement model was correctly specified, the structural model of Figure 1 was estimated to provide an empirical measure of the hypothesized relationships among the research variables and constructs (standardized parameters are shown; solid lines represent significant pathways and correlations between constructs are not shown for clarity). Inspection of the goodness-of-fit measures also provided evidence of a good model fit (see Table 4). 
Figure 2 shows the path diagram with the resulting standardized regression coefficients that are used to indicate the direction and magnitude of relationships among variables. The estimation of the structural model indicates that 14 out of 19 hypotheses were supported (Table 7). The exceptions are the direct effects of perceived ease of use, anxiety, mobile skillfulness and trust on behavioral intention $(\mathrm{H} 2, \mathrm{H} 4, \mathrm{H} 6$ and $\mathrm{H} 10)$, as well as the effect of trust on perceived ease of use ( $\mathrm{H} 12)$. On the contrary, as expected, perceived usefulness exerts a strong positive effect on behavioral intention $(\mathrm{H} 1 ; \beta=0.245, \mathrm{t}=3.237, \mathrm{p}=0.001)$ and perceived ease of use has a strong positive impact on perceived usefulness $(H 3 ; \beta=0.434, t=5.794, p=0.001)$. Anxiety was found to have a strong negative impact on perceived ease of use $(\mathrm{H} 5 ; \beta=-0.354, t=-5.045, \mathrm{p}<0.001)$, thereby supporting our hypothesis. Mobile skillfulness was shown to negatively influence anxiety $(\mathrm{H} 7 ; \beta=-0.738, \mathrm{t}=-15.718, \mathrm{p}<0.001)$, and to positively affect perceived enjoyment $(H 8 ; \beta=0.573, t=14.013, p<0.001)$ and perceived usefulness $(H 9 ; \beta=0.372, t=2,810, p=0.005)$. As anticipated, trust showed a positive relationship towards perceived usefulness $(H 11 ; \beta=0.179, t=2.145, p=0.028)$. Relationship drivers were found to have a positive impact on behavioral intention $(\mathrm{H} 13 ; \beta=0.174, t=2.128, p=$ $0.033)$ and a strong positive impact on perceived usefulness $(\mathrm{H} 14 ; \beta=0.294, t=5.017, p<0.001)$. Moreover, enjoyment has a positive effect on behavioral intention $(\mathrm{H} 15 ; \beta=0.277, t=3.647, p<0.001)$, perceived usefulness $(\mathrm{H} 16 ; \beta=0.511, t=8.537, \mathrm{p}<0.001)$ and perceived ease of use $(\mathrm{H} 17 ; \beta=0.215, t=3.985, p<0.001)$. Finally, innovativeness was found to have marginally significant positive effects on behavioral intention $(H 18 ; \beta=0.200, t=$ 2.016, $p=0.044)$ and perceived ease of use $(\mathrm{H} 19 ; \beta=0.186, t=2.085, p=0.037)$. All in all, over $80 \%$ of the variance in mobile behavioral intention was explained collectively by perceived usefulness, mobile skillfulness, enjoyment, relationship drivers and innovativeness.

Table 7: Path coefficients (standardized regression coefficients)

\begin{tabular}{|c|c|c|c|c|}
\hline Hypothesis & Path & Coefficient & t-value & Significance \\
\hline $\mathrm{H} 1$ & $\mathrm{PU} \rightarrow \mathrm{BI}$ & $0.245^{\star *}$ & 3.237 & 0.001 \\
\hline $\mathrm{H} 2$ & $\mathrm{PEOU} \rightarrow \mathrm{BI}$ & -0.004 & -0.058 & Ns \\
\hline H3 & PEOU $\rightarrow$ PU & $0.434^{\star \star *}$ & 5.794 & $<0.001$ \\
\hline $\mathrm{H} 4$ & ANX $\rightarrow$ BI & -0.094 & -1.116 & Ns \\
\hline $\mathrm{H} 5$ & ANX $\rightarrow$ PEOU & $-0.354^{\star * *}$ & -5.045 & $<0.001$ \\
\hline $\mathrm{H} 6$ & $\mathrm{SKL} \rightarrow \mathrm{BI}$ & 0.122 & 1.359 & Ns \\
\hline $\mathrm{H} 7$ & $\mathrm{SKL} \rightarrow \mathrm{ANX}$ & $-0.738^{* * *}$ & -15.718 & $<0.001$ \\
\hline $\mathrm{H} 8$ & SKL $\rightarrow$ ENJOY & $0.573^{\star * *}$ & 14.013 & $<0.001$ \\
\hline $\mathrm{H} 9$ & $\mathrm{SKL} \rightarrow \mathrm{PU}$ & $0.372^{\star *}$ & 2.810 & 0.005 \\
\hline $\mathrm{H} 10$ & $\mathrm{TR} \rightarrow \mathrm{BI}$ & 0.309 & 1.222 & Ns \\
\hline $\mathrm{H} 11$ & $\mathrm{TR} \rightarrow \mathrm{PU}$ & $0.179^{*}$ & 2.145 & 0.028 \\
\hline $\mathrm{H} 12$ & TR $\rightarrow$ PEOU & 0.114 & 1.722 & $\mathrm{Ns}$ \\
\hline $\mathrm{H} 13$ & $\mathrm{RD} \rightarrow \mathrm{BI}$ & $0.174^{*}$ & 2.128 & 0.033 \\
\hline $\mathrm{H} 14$ & $\mathrm{RD} \rightarrow \mathrm{PU}$ & $0.294^{\star * \star}$ & 5.017 & $<0.001$ \\
\hline $\mathrm{H} 15$ & ENJOY $\rightarrow$ BI & $0.277^{\star \star \star}$ & 3.647 & $<0.001$ \\
\hline $\mathrm{H} 16$ & ENJOY $\rightarrow$ PU & $0.511^{\star * \star}$ & 8.137 & $<0.001$ \\
\hline $\mathrm{H} 17$ & ENJOY $\rightarrow$ PEOU & $0.215^{\star \star \star}$ & 3.985 & $<0.001$ \\
\hline $\mathrm{H} 18$ & INN $\rightarrow$ BI & $0.200^{*}$ & 2.016 & 0.044 \\
\hline $\mathrm{H} 19$ & INN $\rightarrow$ PEOU & $0.186^{*}$ & 2.085 & 0.037 \\
\hline
\end{tabular}

Note: ${ }^{*} p<0.05 ; " p<0.01 ; " p<0.001 ; n s=$ non-significant 


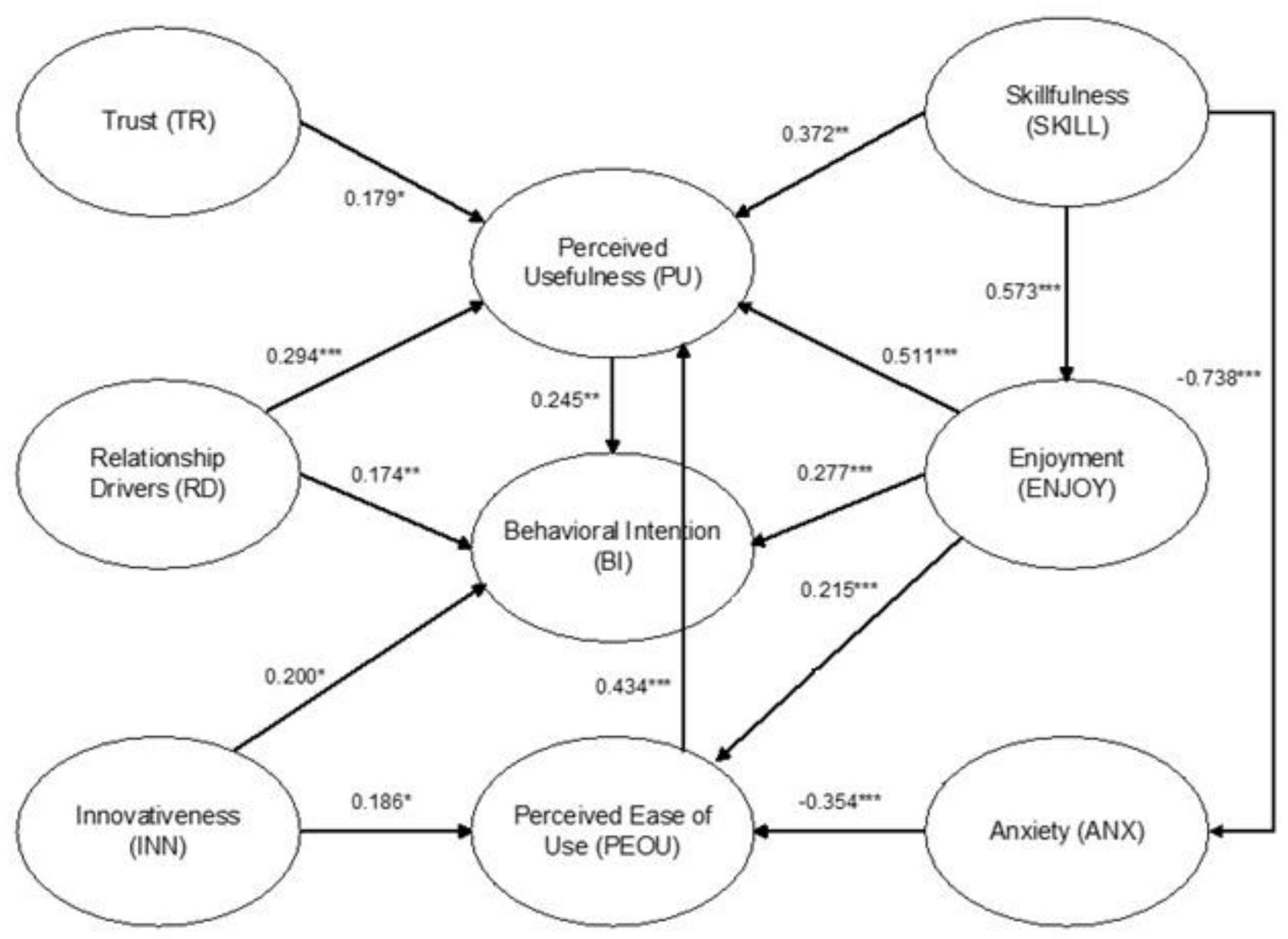

Figure 2: Results of structural model $p<.05, " p<0.01, " * t * 0.001$.

\section{Discussion and Implications}

Mobiles have been long pointed to as the next great communication channel for marketers, and for good reason. A vast majority of today's consumers keep their mobile devices within arm's reach at all times. This positions the smartphone as the consumer's most trusted and important device, all while turning it into the marketer's most direct and reliable engagement vehicle. Traditional marketing and selling strategies and techniques simply don't work for the mobile consumer.

Nonetheless, retailers must commit to continuous business and IT transformation at the same pace as consumers adopt new mobile technologies and shopping behaviors. They need to strengthen their relationships with consumers to the level of trusted partner, which involves providing value (rewards, special treatments and discounts) in return for customers' personal profiles and preference data. Companies must also refine their data-collection and analytics systems, skills and strategies to become more data-driven, in ways that consumers find acceptable.

The present study examines how behavioral intention, perceived usefulness of $\mathrm{m}$-shopping, the perceived ease of buying via mobile devices, trust regarding m-shopping, innovativeness, relationship drivers, mobile skillfulness, enjoyment regarding buying via mobile devices, and anxiety towards mobile shopping co-exist in the same model predicting consumer behavioral intention to adopt $\mathrm{m}$-shopping. Such a study in the mobile domain has not yet been investigated in Greece. The findings of the study offer strong evidence in support of the proposed research model. Based on the resulting model, perceived usefulness and enjoyment emerged as the most informative variables that positively affect behavioral intention. However, all examined variables are recognized as essential factors in the decision to adopt mobile technologies because they affect directly or indirectly behavioral intention. Thus, the results have important implications for practitioners, especially application developers, mobile marketing managers, mobile product \& services providers and scholars, who are keen on studying technology acceptance models and mobile customers' behavior. Consequently, the contribution of this article is multi-sided: First, the article contributes to the 
development and evolution of a theoretical and conceptual model for examining its effect on customers' intention to adopt mobile shopping; it builds on the growing literature of the Behavioral Intention Theory. The concurrent combination of drivers, used as parameters to predict the customers' behavior regarding mobile shopping has not been tested before in the literature. Most of them-as they are analyzed in the next section-have been examined separately, or as parts of other conceptual models; this survey's model is newly suggested. Additionally, the current survey is conducted in a country, where scarce similar studies have taken place. Finally, the conceptual model uses perspectives from the marketing area for a technology acceptance issue by including the relationship drivers, the enjoyment and the anxiety constructs, examining possible marketing solutions related to the mobility characteristics. Relationship drivers were found to have a positive impact on behavioral intention and a strong positive impact on perceived usefulness. It should be mentioned that companies which provide mobile products and services or organizations that provide mobile services and solutions should take advantage of the relationship ties that $\mathrm{m}$ shopping activities are able to create with their users. This is accomplished through personalized services, which are optional and can be reached anytime at any place. M-shopping solutions should be equipped with functions which render customers' attitudes about benefits and enjoyment significant. Likewise, m-providers should focus on the benefits of $\mathrm{m}$-shopping through advertising campaigns taking advantage of location based activities. They have to prove to their customers that they will save money and time facilitating the buying process, in order to increase the m-shopping intention. M-coupons can also attract the m-shoppers, focusing on the simplification of their exchange (e.g. direct reduction of the price instead of a reduction offered for the next purchase), a fact that would contribute with clear positive attributes to m-shopping. Moreover, enjoyment has a positive effect on behavioral intention and perceived usefulness. The idea of correlating the adoption intention of the $\mathrm{m}$-services with the relationship ties including coupons, rewards, further offers and location based marketing activities, that are possible to be created by their own use is quite innovative and very specialized in the mobile features of the considered technology. Non-store formats of shopping can offer satisfaction to profiles of shoppers who are internet literate and technology fans. Those types of consumers can correlate the shopping process with an innovative shopping channel, which offers them pleasure. That is the reason that enjoyment has been found to be a factor with a positive impact on online shopping intention. Additionally, apart from behavioral intention of mobile shopping factor of the proposed model, the findings of our analyses show the correlation between enjoyment and perceived usefulness and perceived ease of use, proving that perceived enjoyment is a significant predictor of perceived usefulness, perceived ease of use, and intention to adopt mobile shopping.

The results of this study suggest an enriched acceptance model of mobile shopping intention. In the proposed model not all of the initial hypotheses are verified. The estimation of the structural model indicates that 14 out of 19 hypotheses were supported (Table 8). The exceptions are the direct effects of perceived ease of use, anxiety, mobile skillfulness and trust on behavioral intention, as well as the effect of trust on perceived ease of use. On the other hand, perceived usefulness exerts a strong positive effect on behavioral intention and perceived ease of use has a strong positive impact on perceived usefulness. Anxiety was found to have a strong negative impact on perceived ease of use, thereby supporting our hypothesis. Mobile skillfulness was shown to negatively influence anxiety, and to positively affect perceived enjoyment and perceived usefulness. As anticipated, trust showed a positive relationship towards perceived usefulness. Finally, innovativeness was found to have marginally significant positive effects on behavioral intention. Individual innovation is one of the embodiments of those individual differences, which actually means individuals' character tendency in trying new technologies. Researches have proved that the individual character of innovation is closely related to their attitude towards online shopping [116].

Summarizing, over $80 \%$ of the variance in mobile behavioral intention was explained collectively by perceived usefulness, mobile skillfulness, enjoyment, relationship drivers and innovativeness.

This survey's conclusions can grow mobile subject matter expertise and support practitioners evaluating their development solutions, based on the factors influencing the mobile consumers' behavior. Thus, companies and organizations involved in the mobile applications, mobile commerce and mobile marketing could use them as a consultancy tool while organizing their mobile strategies based on consumer-preferred tactics and offerings and implementing their business ideas in order to motivate their customers to use mobile devices to purchase products and services online.

\subsection{Limitations and Future Work}

Despite the fact that the aforementioned results provide meaningful implications, the research can be further improved by overtaking some important limitations. It would be of high interest, to investigate the behavior of the model after the addition of other constructs suggested by the literature, such as social influence drivers. Social networking might have a positive influence on behavioral intention regarding mobile shopping and affect the relationships between existing factors. Moreover, further evidence from heterogeneous samples is needed to ensure that the observed relationships are similar across different gender, education or age groups. Additionally, it is to be emphasized that these findings are limited to a sample of Greek consumers. Similar studies could be conducted in other countries, taking into consideration the different cultural notions in order to get comparative data for a crosscultural study or a meta-analysis of existing studies. Such a comparison could be beneficial for the mobile marketing strategy targeting to multicultural mobile products and services. As the consumer's cultural background is one of the aspects which can influence the creation of a favorable climate for developing and consolidating electronic 
transactions, we consider that another interesting line of research would be to contrast the validity of the proposed behavioral model with samples of consumers from other cultures and compare the results obtained.

Furthermore, regarding future research, we think it would be very useful to complement this study with the development and validation of a scale to measure m-shopping motivations and perceived risk, taking into consideration attitudinal variables such as motivations and barriers on mobile shopping decisions.

There is no doubt that the success of this new direct sales channel will be conditioned by both the group of product/ service offered and their cost.

\section{References}

[1] N. Achadinha, L. Jama and P. Nel, The drivers of consumers' intention to redeem a push mobile coupon, Behaviour \& Information Technology, vol. 33, no. 12, pp. 1306-1316, 2014.

[2] R. Agarwal and J. Prasad, A conceptual and operational definition of personal innovativeness in the domain of information technology, Information Systems Research, vol. 9, no. 2, pp. 204-215, 1998.

[3] N. Aharony, Librarians' attitudes towards mobile services, Aslib Proceedings, vol. 65, no. 4, pp. 358-375, 2013.

[4] I. Ajzen, The theory of planned behavior, Organizational Behavior and Human Decision Processes, vol. 50, no. 2, pp. 179-211, 1991.

[5] U. Akturan and N. Tezcan, Mobile banking adoption of the youth market perceptions and intentions, Marketing Intelligence \& Planning, vol. 30, no. 4, pp. 444-459, 2012.

[6] S. Alawadhi and A. Morris, The use of the UTAUT model in the adoption of e-government services in Kuwait, in Proceedings of the 41st Hawaii International Conference on System Sciences, Hawaii, USA, 2008, pp. 1-5.

[7] J. Aldas-Manzano, C. Ruiz-Mafe and S. Sanz-Blas, Exploring individual personality factors as drivers of $\mathrm{m}$ shopping acceptance, Industrial Management \& Data Systems, vol. 109, no.6, pp. 739-757, 2009.

[8] J. Anderson and P. Schwager, SME adoption of wireless LAN technology: Applying the UTAUT model, in Proceedings of the 7th Annual Conference of the Southern Association for Information Systems, Savannah, Georgia, USA, 2003, pp. 39-43.

[9] N. Androulidakis and I. Androulidakis, Perspectives of mobile advertising in Greece, in Proceedings of the 4th International Conderence on Mobile Business, Sydney, Australia, 2005, pp. 441-444

[10] R. P. Bagozzi and Y. Yi, On the evaluation of structural equation models, Journal of the Academy of Marketing Science, vol. 16, no. 1, pp. 74-94, 1988

[11] B. Bahli and Y. Benslimane, An exploration of wireless computing risks, Information Management \& Computer Security, vol. 12, no. 3, pp. 245-254, 2004.

[12] A. Bailey, I. Pentina, A. S. Mishra and M. S. B. Mimoun, Mobile payments adoption by US consumers: An extended TAM, International Journal of Retail \& Distribution Management, vol. 45, no. 6, pp. 626-640, 2017.

[13] S. Balasubramanian, R. A. Peterson and S. L. Jarvenpaa, Exploring the implications of m-commerce for markets and marketing, Journal of the Academy of Marketing Science, vol. 30, no. 4, pp. 348-61, 2002.

[14] K. Benedict. (2014, November) Cutting Through Chaos in the Age of Mobile Me. Cognizant. [Online]. Available: https://www.cognizant.com/InsightsWhitepapers/Cutting-Through-Chaos-in-the-Age-of-Mobile-Mecodex1579.pdf.

[15] P. M. Bentler, Comparative fit indexes in structural models, Psychological Bulletin, vol. 107, no. 2, pp. 238-246, 1990.

[16] A. Bhattacherjee, Individual trust in online firms: Scale development and initial test, Journal of Management Information Systems, vol. 19, no. 1, pp. 211-241, 2002

[17] M. W. Browne and R. Cudeck, Alternative ways of assessing model fit, in Bollen (K. A., Long and J. S., Eds.). Testing Structural Equation Models, Newbury Park, CA: Sage, 1993, pp. 136-162.

[18] J. Chen and L. Tong, Analysis of mobile phone's innovative will and leading customers, Science Management, vol. 24, no. 3, pp. 25-31, 2003.

[19] L. A. Chen, A model of consumer acceptance of mobile payment, International Journal of Mobile Communications, vol. 6, no. 1, pp. 32-52, 2008.

[20] D. Y. Cho, H. J. Kwon and H. Y. Lee, Analysis of trust in internet and mobile commerce adoption, in Proceedings of the 40th Hawaii International Conference on System Science, Honolulu, HI, USA, 2007, pp. 110.

[21] A. Y. L. Chong, A two-staged SEM-neural network approach for understanding and predicting the determinants of $\mathrm{m}$-commerce adoption, Expert Systems with Applications, vol. 40, pp. 1240-1247, 2013.

[22] D. R. Compeau, C. A. Higgins and S. Huff, Social cognitive theory and individual reactions to computing technology: a longitudinal study, MIS Quarterly, vol. 23, no. 2, pp. 145-58, 1999.

[23] M. Crabbe, C. Standing and S. Standing, An adoption model for mobile banking in Ghana, International Journal of Mobile Communications, vol. 7, no. 5, pp. 515-543, 2009.

[24] H. Dai and P. C. Palvia, Mobile commerce adoption in China and the United States: A cross-cultural study, The Data Base for Advances in Information Systems, vol. 40, no.4, pp. 43-61, 2009.

[25] C. H. Davis and F. Vladica, Adoption and use of internet technologies and e-business solutions by Canadian micro-enterprises, in Proceedings Annual Conference of the International Association for Management of Technology, Vienna, 2005. 
[26] D. Davis, Perceived usefulness, perceived ease of use and user acceptance of information technology, MIS Quarterly, vol.13, no. 3, pp. 319-340, 1989.

[27] F. Davis, R. Bagozzi and P. Warshaw, Extrinsic and intrinsic motivation to use computers in the workplace, Journal of Applied Social Psychology, vol. 22, no. 14, pp. 1111- 1132, 1992.

[28] Deloitte. (2016, December) Global mobile consumer survey 2016: Trends from around the world. Deloitte. [Online]. Available: https://www2.deloitte.com/global/en/pages/technology-media-and-telecommunications/arti cles/glo bal-mobile-consumer-survey.html.

[29] X. Deng, W. Doll and D. Truong, Computer self-efficacy in an ongoing use context, Behaviour and Information Technology, vol. 23, no. 6, pp. 395-412, 2004

[30] S. Doyle, Software review: Using short message services as a marketing tool, Journal of Database Marketing, vol. 8, no. 3, pp. 273-277, 2001

[31] M. H. Fagan, S. Neill and B. R. Wooldridge, An empirical investigation into the relationship between computer self-efficacy, anxiety, experience, support and usage, Journal of Computer Information Systems, vol. 44, no. 2, pp. 95-104, 2003.

[32] T. Fenech, Exploratory study into wireless application protocol shopping, International Journal of Retail \& Distribution Management, vol. 30, no. 10, pp. 482-497, 2002.

[33] M. Fishbein and I. Ajzen, Belief, Attitude, Intention and Behavior: An Introduction to Theory and Research. MA: Addison-Wesley, 1975.

[34] L. Flynn and R. Goldsmith, A validation of the Goldsmith and Hofacker innovativeness scale, Educational and Psychological Measurement, vol. 53, pp. 1105-1116, 1993.

[35] C. Fornell and D. F. Larcker, Structural equation models with unobservable variables and measurement error: Algebra and statistics, Journal of Marketing Research, vol. 18, no. 3, pp. 382-388, 1981.

[36] M. Frank, P. Roehrig and B. Pring, Code halos: How the digital lives of people, things, and organizations are changing the rules of business. New Jersey: Wiley \& Sons, 2014

[37] D. Gefen and D.W. Straub, Managing user trust in B2C e-services, E-Service Journal, vol. 2, no. 2, pp. 7-24, 2003.

[38] M. Grob, Exploring the acceptance technology for mobile shopping: an empirical investigation among smartphone users, The International Review of Retail, Distribution and Consumer Research, vol. 25, no. 3, pp. 215-235, 2014.

[39] P. Guriting and N. Ndubisi, Borneo online banking: Evaluating customer perceptions and behavioural intention, Management Research News, vol. 29, no. 1/2, pp. 6-15, 2006.

[40] S. Ha and L. Stoel, Consumer e-shopping acceptance: Antecedents in a technology acceptance model, Journal of Business Research, vol. 62, no. 5, pp. 565-571, 2009.

[41] J. Hair and W. Black, Babin, B., Anderson, R., Multivariate Data Analysis 7th edition. New Jersey: Pearson/Prentice Hall, 2014.

[42] P. Hanafizadeh, M. Behboudi, A. A. Koshksaray, M. Jalilvand, and S. Tabar, Mobile-banking adoption by Iranian bank clients, Telematics and Informatics, vol. 31, no. 1, pp. 62-78, 2014

[43] C. Hart, A. Farrell, G. Stachow, G. Reed and J. Cadogan, Enjoyment of the shopping experience: Impact on customers' repatronage intentions and gender influence, Service Industries Journal, vol. 27, no. 5, pp. 583-604, 2007.

[44] K. Heinonen and M. Pura, Classifying mobile services, in Proceedings of Helsinki Mobility Roundtable, Sprouts: Working Papers on Information Systems, vol. 6, no. 42, 2006.

[45] A. Holmes, A. Byrne and J. Rowley, Mobile shopping behaviour: Insights into attitudes, shopping process involvement and location, International Journal of Retail \& Distribution Management, vol. 42 no. 1, pp. 25-39, 2014.

[46] S. Hong, J. Thong and K. Tam, Understanding continued information technology usage behavior: A Comparison of three models in the context of Mobile Internet, Decision Support Systems, vol. 42, no. 3, pp. 1819-1834, 2006.

[47] B. Hourahine and M. Howard, Money on the move: Opportunities for financial service providers in the Third Space, Journal of Financial Services Marketing, vol. 9, no. 1, pp. 57-67, 2004.

[48] L. T. Hu and P. M. Bentler, Cutoff criteria for fit indexes in covariance structure analysis: Conventional criteria versus new alternatives, Structural Equation Modeling, vol. 6, no. 1, pp. 1-55, 1999.

[49] M.-C. Hung, S.-T. Yang and T. Hsieh, An examination of the determinants of mobile shopping continuance, International Journal of Electronic Business Management, vol. 10, no. 1, pp. 29-37, 2012.

[50] J. Ignatius and T. Ramayah, An empirical investigation of the course website acceptance model (CWAM), International Journal of Business and Society, vol. 6, no. 2, pp. 69-82, 2005.

[51] I. Im, Y. Kim and H. Han, The effects of perceived risk and technology type on users' acceptance of technologies, Information \& Management, vol. 45, no. 1, pp. 1-9, 2008.

[52] S. L. Jarvenpaa and K. R. Lang, Managing the paradoxes of mobile technology, Information Systems Management, vol. 22, no. 4, pp. 7-23, 2005.

[53] S. Jayasingh and U. C. Eze, An empirical analysis of consumer behavioral intention toward mobile coupons in Malaysia, International Journal of Business and Information, vol. 4, no. 2, pp. 221-242, 2015.

[54] W.-J. K. Jih and S.-F. Lee, An exploratory analysis of relationships between cellular phone uses' shopping motivators and lifestyle indicators, Journal of Computer Information Systems, vol. 44, no. 2, pp. 65-73, 2003.

[55] B.Jin and B. Sternquist, Shopping is truly a joy, The Service Industries Journal, vol. 24, no. 6, pp. 1-18, 2004.

[56] L. June, Are personal innovativeness and social influence critical to continue with mobile commerce?, Internet Research, vol. 24, no. 2, pp.134-159, 2014. 
[57] Z. Kalinic and V. Marinkovic, Determinants of users' intnetion to adopt m-commerce: An empirical analysis, Information Systems and e-Business Management, vol. 14, no. 2, pp. 367-387, 2016

[58] P. K. Kannan, A. Chang and A. B. Whinston, Wireless commerce: Marketing issues and possibilities, in Proceedings of the 34th Hawaii International Conference on System Sciences, Hawaii, 2001, pp. 1-6.

[59] M. Khalifa and K. N. Shen, Drivers for transitional B2C m-commerce adoption: Extended Theory for planned behaviour, The Journal of Computer Information Systems, vol. 48, no. 3, pp. 111-117, 2008.

[60] G. S. Kim, S.-B. Park and J. Oh, An examination of factors influencing consumer adoption of short message service (SMS), Psychology \& Marketing, vol. 25, no. 8, pp. 769-786, 2008.

[61] R. B. Kline, Principles and Practice of Structural Equation Modeling 2nd edition. New York: The Guilford Press, 2005.

[62] P. Kourouthanassis and G. Giaglis, Introduction to the special issue mobile commerce: The past, present, and future of mobile commerce research, International Journal of Electronic Commerce, vol. 16, no. 4, pp. 5-18, 2012.

[63] Y. Kuo and S. Yen, Towards an understanding of the behavioral intention to use $3 G$ mobile value-added services, Computers in Human Behavior, vol. 25, no. 1, pp. 103-110, 2009.

[64] H. Lu and P. Su, Factors affecting purchase intention on mobile shopping websites, Internet Research, vol. 19, no. 4, pp. 442-458, 2009

[65] J. Lu, Are personal innovativeness and social influence critical to continue with mobile commerce? Internet Research, vol. 24, no. 2, pp. 134-159, 2014.

[66] P. Luarn and H.-H. Lin, Toward an understanding of the behavioral intention to use mobile banking, Computers in Human Behavior, vol. 21, no. 6, pp. 873-891, 2005.

[67] D. J. McFarland and D. Hamilton, Adding contextual specificity to the technology acceptance model, Computers in Human Behavior, vol. 22, no. 3, pp. 427-447, 2006.

[68] M. L. Meuter, A. L. Ostrom, M. J. Bitner, and R. Roundtree, The Influence of technology anxiety on consumer use and experiences with self-service technologies, Journal of Business Research, vol. 56, no. 11, pp. 899906, 2003.

[69] D. Midgley and G. Dowling, Innovativeness: The concept and its measurement, Journal of Consumer Research, vol. 4, no. 4, pp. 229-242,1978.

[70] Q. Min, S. Ji and G. Qu, Mobile commerce user acceptance study in China: A revised UTAUT model, Tsinghua Science \& Technology, vol. 13, no. 3, pp. 257-264, 2008.

[71] M. K. Moorty, C. W. Sann, C. Y. Ling, T. P. Yin, W. K. Yan, and Y. Y. Ee, Adoption of mobile commerce in Malaysia: A generation perception, International Journal of Research, vol. 1, no. 8, pp. 825-845, 2014.

[72] R. M. Morgan, Relationship marketing and marketing strategy: The evolution of relationship marketing within the organization, in Handbook of Relationship Marketing (J. Sheth and A. Parvatiyar, (Eds.). Thousand Oaks, CA: Sage, 2000 , pp. 481-505.

[73] L. K. Muthén and B. O. Muthén, Mplus for Windows 7.31. Los Angeles: Muthén \& Muthén, 2015.

[74] E.W. T. Ngai, Gunasekaran, A., A review for mobile commerce research and applications, Decision Support Systems, vol. 43, no. 1, pp. 3-15, 2007.

[75] Nielsen. (2013, February). The mobile consumer: A global snapshot. Nielsen. [Online]. Available: http://www.nielsen.com/content/dam/corporate/us/en/reports-downloads/2013\%20Reports/Mobile-ConsumerReport-2013.pdf

[76] A. Nikander, Determinants of consumer intentions to redeem mobile coupons, M.S. Thesis. Department of Management and International Business, Aalto Univeristy, Finland, 2011.

[77] H. Nysveen, P. Pedersen, H. Thorbjornsen, and P. Berthon, Mobilizing the brand: The effects of mobile services on brand relationships and main channel use, Journal of Service Research, vol. 7, no. 3, pp. 257-276, 2005.

[78] P. Pavlou, Consumer acceptance of electronic commerce: Integrating trust and risk with the technology acceptance model, International Journal of Electronic Commerce, vol. 7, no. 3, pp. 101-134, 2003.

[79] A. Persaud and I. Azhar, Innovative mobile marketing via smartphones: Are consumers ready? Marketing Intelligence \& Planning, vol. 30, no. 4, pp. 418-443, 2012.

[80] I. Petina, A. Amialchuk and D. Taylor, Exploring effects of online shopping experiences on browser satisfaction and e-tail performance, International Journal of Retail \& Distribution Management, vol. 39, no. 4, pp. 742-758, 2011.

[81] P. M. Podsakoff, S. B. MacKenzie and J. Y. Lee, Podsakoff, N. P., Common method biases in behavioral research: A critical review of the literature and recommended remedies, Journal of Applied Psychology, vol. 88, no. 5, pp. 879-903, 2003

[82] J. Qi, L. Li, Y. Li, and H. Shu, An extension of technology acceptance model: Analysis of the adoption of mobile data services in China, Systems Research and Behavioral Science, vol. 26, no. 3, pp. 391-407, 2009.

[83] J. Ramayah and J. Ignatius, Impact of perceived usefulness, perceived ease of use and perceived enjoyment on intention to shop online, ICFAI Journal of Systems Management, vol. 3, no. 3, pp. 36-51, 2005.

[84] T. Ramayah, Interface characteristics, perceived ease of use and intention to use an online library in Malaysia, Information Development, vol. 22, no. 2, pp. 123-133, 2006.

[85] E. Rogers, Diffusion of Innovations 4th edition. New York: The Free Press, 1995.

[86] S. San-Martín, B. López-Catalán and M. Ramón-Jerónimo, Mobile shoppers: types, drivers, and impediments, Journal of Organizational Computing and Electronic Commerce, vol. 23, no. 4, pp. 350-371, 2013.

[87] A. Scharl, A. Dickinger and J. Murphy, Diffusion and success factors of mobile marketing, Electronic Commerce Research and Applications, vol. 4, no. 2, pp. 159-173, 2005 
[88] P. Schierz, O. Schilke and B. Wirtz, Understanding consumer acceptance of mobile payment services: An empirical analysis, Electronic Commerce Research and Applications, vol. 9, no. 3, pp. 209-216, 2010

[89] Scoop Media. (2013, April). Smartphone adoption driving mobile shopping habits. Scoop. [Online]. Available: http://www.scoop.co.nz/stories/BU1304/S00321/smartphone-adoption-driving-mobile-shopping-habits.htm.

[90] S. K. Sharma, S. M. Govindaluri, S. Al-Muharrami, and A. Tarhini, A multi-analytical model for moble banking adoption: a developing country perspective, Review of International Business and Strategy, vol. 27, no. 1, pp. 133-148, 2017

[91] B. Suh and I. Han, Effect of trust on customer acceptance of Internet banking, Electronic Commerce Research and Applications, vol. 1, no. 3-4, pp. 247-263, 2002

[92] Q.Sun, C. Wang and H. Cao, An extended TAM for analyzing adoption behavior of mobile commerce, in Proceedings of the 8th international conference on mobile business, Dalian, China, 2009, pp. 52-56.

[93] B. Tariq, Exploring factors influencing the adoption of moble commerce, Journal of Internet Banking and Commerce, vol. 12, no. 3, pp. 32-42, 2007.

[94] S.Taylor and P. A. Todd, Understanding information technology usage: A test of competing models, Information Systems Research, vol. 6, no. 2, pp. 144-176, 1995.

[95] T. S. H. Teo and R. Y. C. Lim, Intrinsic and extrinsic motivation in Internet usage, OMEGA: International Journal of management Science, vol. 27, no. 1, pp. 25-37, 1999.

[96] T. Teo and J. Noyes, An assessment of the influence of perceived enjoyment and attitude on the intention to use technology among pre-service teachers: A structural equation modeling approach, Computers and Education, vol. 57, no. 2, pp. 1645-1653, 2011

[97] J. Thong, S. J. Hong and K. Y. Tam, The effects of post-adoption beliefs on the expectation-confirmation model for information continuance, International Journal of Human-Computer Studies, vol. 64, no. 9, pp. 799-810, 2006.

[98] V. Venkatesh, M. Morris, G. Davis and F. Davis, User acceptance of information technology: Toward a unified View, MIS Quarterly, vol. 27, no. 3, pp. 425-478, 2003.

[99] Vibes. (2016, month) Mobile consumer report. Vibes. [Online]. Available: http://www.vibes.com/resources/2016mobile-consumer-report

[100] K. L. Wakefield and J. Baker, Excitement at the mall: Determinants and effects on shopping response, Journal of Retailing, vol. 74, no. 4, pp. 515-539, 1998.

[101]R. Walczuch, J. Lemmink and S. Streukens, The effect of service employees' technology readiness on technology acceptance, Information \& Management, vol. 44, no. 2, pp. 206-215, 2007.

[102] C. Wang, S. Lo and W. Fang, Extending the technology acceptance model to mobile telecommunication innovation: The existence of network externalities, Journal of Consumer Behaviour, vol. 7, no. 2, pp. 101-110, 2008.

[103]Y. Wang and Y. W. Liao, The conceptualization and measurement of m-commerce user satisfaction, Computers in Human Behavior, vol. 23, no. 1, pp. 381-398, 2007.

[104]Y. Wang, H. Lin and P. Luarn, Predicting consumer intention to use mobile service, Information Systems Journal, vol. 16, no. 2, pp. 157-179, 2006

[105] R. Watson, F. Pitt, P. Berthon and G. Zinkhan, U-Commerce: expanding the universe of marketing, Journal of the Academy of marketing science, vol. 30, no. 4, pp. 333-347, 2002.

[106] T. Wei, G. Marthandan, A. Chong, K. Ooi and S. Arumugam, What drives Malaysian m-commerce adoption? An empirical analysis, Industrial Management \& Data Systems, vol. 109, no. 3, pp. 370-388, 2009.

[107] J. Wu and S. Wang, What drives mobile commerce? An empirical evaluation of the revised technology acceptance model, Information \& Management, vol. 42, no. 5, pp. 719-729, 2005.

[108] I. L. Wu, J. Y. Li and C. Y. Fu, The adoption of mobile healthcare by hospital's professionals: An integrative perspective, Decision Support Systems, vol. 51, no. 3, pp. 587-596, 2011.

[109]R. Yadav, S. K. Sharma and A. Tarhini,A multi-analytical approach to understand and predict the mobile commerce adoption, Journal of Enterprise Information Management, vol. 29, no. 2, pp. 222-237, 2016.

[110] K. Yang, Exploring factors affecting the adoption of mobile commerce in Singapore, Telematics and Informatics, vol. 22, no. 3, pp. 257-277, 2005.

[111]K. Yang and J. C. Forney, The moderating role of consumer technology anxiety in mobile shopping adoption: Differential effects of facilitating conditions and social influences, Journal of Electronic Commerce Research, vol. 14, no. 4, pp. 334-347, 2013.

[112]K. Yang and H.-Y. Kim, Mobile shopping motivation: An application of multiple discriminant analysis, International Journal of Retail \& Distribution Management, vol. 40, no. 10, pp. 778-789, 2012

[113]M. Yi, J. Jackson, J. Park and J. Probst, Understanding information technology acceptance by individual professionals: Toward an integrative view, Information \& Management, vol. 43, no. 3, pp. 350-363, 2006.

[114]Y. Yu, Buahom, K., Exploring factors influencing consumer adoption on mobile commerce services, The Business Review, Cambridge, vol. 21, no. 1, pp. 258-265, 2013.

[115]T. Zarmpou, V. Saprikis, A. Markos and M. Vlachopoulou, Modeling users' acceptance of mobile services, Electronic Commerce Research, vol. 12, no. 2, pp. 225-248, 2012.

[116] C. Zhong, Critical factor analysis of mobile online shopping adoption: from mobile phone users' perspectives, in Proceedings of International Conference on Computational and Information Sciences, Shiyan, Hubai, China, 2013, pp. 1668-1670. 